\title{
Vida Saludable para Personas de Edad: No Olvide Tomar Sus Medicamentos ${ }^{1}$
}

\section{Linda B. Bobroff ${ }^{2}$}

Los medicamentos ayudan a controlar un número importante de enfermedades y afecciones. Pero las medicinas solo funcionan si usted recuerda tomarlas! Seleccione los consejos de la lista que le puedan ayudar a recordar tomarse sus medicinas.

- Notas en el refrigerador: Ponga una foto suya o de una persona allegada en su refrigerador, junto con una nota que le recuerde tomar sus medicinas.

- Manténgalas en su mesa de noche: Si tiene que tomar sus medicinas por la mañana, ésta puede ser una buena manera de recordarlo.

- Use pastilleros semanales: Estas pequeñas cajas para guardar píldoras pueden conseguirse en la mayoría de las farmacias.

- Use notas adhesivas: Ponga notas adhesivas que le recuerden tomar sus medicamentos en sitios donde usted las vaya a ver.

- Servicio de mensajes: Si tiene acceso a este servicio, usted puede grabar un mensaje que le recuerde tomar sus medicinas y hacer que automáticamente el servicio le mande este mensaje todos los días.

- Sistema del amigo: Haga un pacto con un amigo en el que ustedes se llamen mutuamente todos los días para recordarle el uno al otro de tomar sus medicinas.

- Pídale a sus nietos que le llamen: Pídale a sus nietos u otros familiares que le llamen todos los días y le recuerden tomar sus medicinas.

- Mensaje inicial en su computadora: Usted puede programar su computadora para que le aparezca un mensaje recordándole tomar sus medicinas cada vez que la encienda.

- Pongalas junto a su cepillo de dientes: Tome sus medicinas después de lavarse los dientes.

1. This is document FCS 8600-SPAN, one in a series of the Department of Family, Youth and Community Sciences, Florida Cooperative Extension Service, Institute of Food and Agricultural Sciences, University of Florida, Gainesville, FL 32611. Publication date: March 2004. This leaflet was developed with funding from the Department of Elder Affairs in partnership with state, county, and local agencies. Please visit the EDIS Web site at http://edis.ifas.ufl.edu

2. Linda B. Bobroff, PhD, RD, LD/N, professor, Department of Family, Youth and Community Sciences, Institute of Food and Agricultural Sciences, University of Florida, Gainesville, FL 32611. Reviewed by Jennifer Hillan, MSH, RD, LD/N, former ENAFS educator/trainer, University of Florida. Translated by Sergio Romero, MS, ATC, University of Florida. Translation reviewed by Isabel Valentín-Oquendo, MS, RD, former FNP curriculum coordinator, University of Florida.

The Institute of Food and Agricultural Sciences (IFAS) is an Equal Employment Opportunity - Affirmative Action Employer authorized to provide research, educational information and other services only to individuals and institutions that function without regard to race, creed, color, religion, age, disability, sex, sexual orientation, marital status, national origin, political opinions or affiliations. For information on obtaining other extension publications, contact your county Cooperative Extension Service office. Florida Cooperative Extension Service / Institute of Food and Agricultural Sciences / University of Florida / Larry R. Arrington, Interim Dean 